Research.

\title{
Company size, sales growth and leverage against tax avoidance in property and real estate companies on the Indonesian Stock Exchange for the period of 2012-2018
}

\author{
Agung Fajar IImiyono1), Rima Auliyamartha Agustina ${ }^{2)^{*}}$ \\ ${ }^{1)}$ Department of Accountancy, Universitas Pakuan Bogor, Indonesia \\ ${ }^{2)}$ Department of Accountancy, Universitas Binaniaga Indonesia, Bogor, Indonesia \\ 1) agung.fajar@unpak.ac.id ${ }^{2)}$ atha.martha84@gmail.com \\ * Corresponding author
}

Received: September 25, 2020; Accepted: November 14,2020; Published: December 31, 2020

To cite this article: Ilmiyono, A.F. \& Agustina,R.A. (2020). Company size, sales growth and leverage against tax avoidance in property and real estate companies on the Indonesian Stock Exchange for the period Of 20122018. The Accounting Journal of BINANIAGA. 5 (2), 85-100. doi: 10.33062/ajb.v5i2. 389

\begin{abstract}
The difference in tax interests between companies and the government encourages companies to regulate the amount of tax burden to be paid, a strategy that is usually used by companies, namely tax avoidance, besides that the tax ratio in Indonesia has decreased from 2012-2017. This phenomenon shows that tax avoidance is still being carried out. This research aims to examine the effect of company size, sales growth, and leverage on tax avoidance in property and real estate companies listed on the IDX in the period 2012-2018. Twenty-one samples were tested with classical assumption test, using multiple regression analysis techniques. The results show that partially company size has an effect on tax avoidance, sales growth has no effect on tax avoidance and leverage has an effect on tax avoidance. Simultaneously, company size, sales growth and leverage have an effect on tax avoidance.
\end{abstract}

Keywords: Leverage, Sales Growth, Tax Avoidance and Company Size

\section{INTRODUCTION}

\section{Background}

Taxes for companies are a burden that can reduce corporate profits, while taxes for the state are state revenues from the tax sector which will be used to fund governance and play a very important role for the continuity of a country's government system. Based on the 2018 State Budget, state revenue is IDR 1,894.7 T, and in the amount of IDR $1,618.1 \mathrm{~T}$ or $85.4 \%$ of the income came from tax revenue.

The difference in interests between the government and the company encourages companies to regulate the amount of tax to be paid by the company. The strategy that can be done to reduce taxes, namely tax avoidance, is an effort to minimize the tax burden that is often carried out by companies, because it is still within the framework of the applicable tax regulations. The phenomenon of tax avoidance in Indonesia can be seen from the tax ratio of the Indonesian state, the higher the tax ratio of a country, the better the country's tax collection performance. The following is the data regarding Indonesia's tax ratio for the period 2012-2018 which is presented in the figure below.

Agung Fajar IImiyono and Rima Auliyamartha Agustina. Company size, sales growth and leverage against tax avoidance in property and real estate companies on the Indonesian Stock Exchange for the period of 2012-2018 
Figure 1 Indonesia's Tax Ratio 2012- 2018

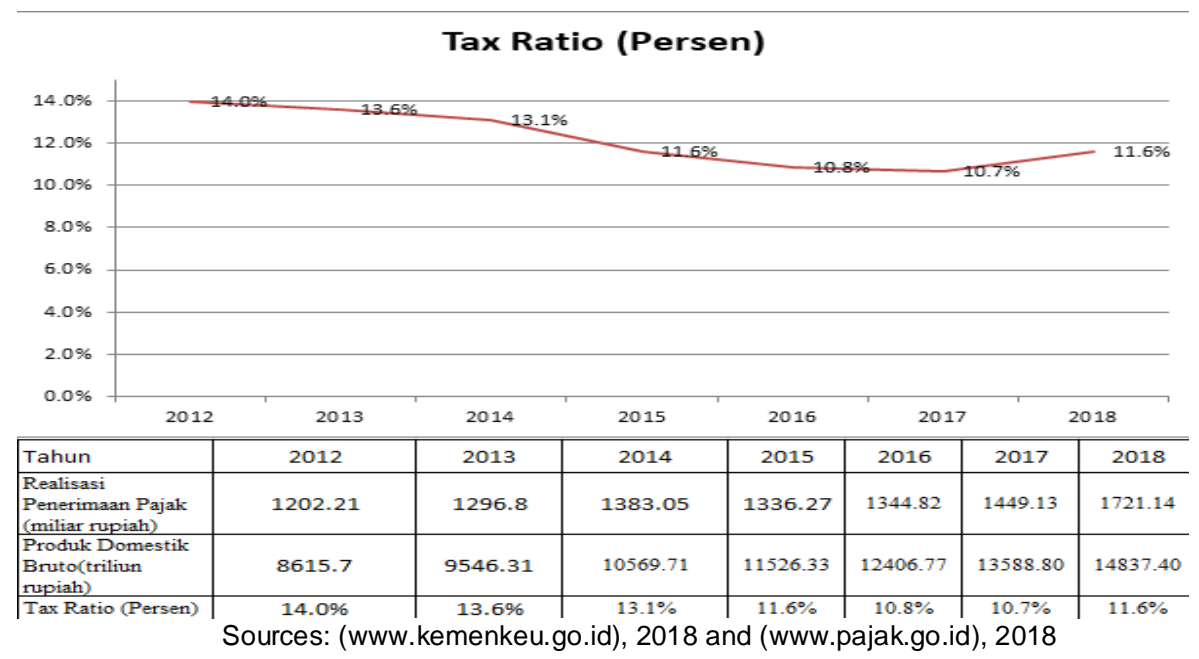

Through this data, the tax ratio for the last 7 (seven) years, namely from 2012-2018 shows a decline from 2012-2017 and has increased in 2018. This indicates that the tax revenue used by the state has not been optimal in 2012-2017. Abroad and in Indonesia itself, there are still many cases of tax avoidance, such as tax evasion by Singaporebased healthcare companies, namely PT RNI (kompas.com) and PT Adaro Energy (tirto.id).

There are many factors that can lead to tax avoidance, one of which is the size of the company, according to Handayani and Wulandari (2014) in Wijayanti and Merkusiwati (2017). it gets more and more complex. So it allows companies to take advantage of existing loopholes to take tax avoidance actions from each transaction. Dewinta and Setiawan (2016) stated that sales growth is also one of the factors that affect tax avoidance. The more sales growth shows that the greater the profit the company will get, which will have an impact on the high tax costs that must be paid. Therefore, companies do tax avoidance so that the company's burden is not high. The next factor is leverage; according to Surbakti (2012) leverage is a funding policy where the level of debt is used by the company to finance its operating activities. The increase in the amount of debt will cause an interest expense to be paid by the company. The interest expense incurred on the debt will be used as a deduction for the company's net profit which will reduce tax payments.

Based on article 17 of Law no. 36 of 2008 concerning income tax, the tax rate on entities is $25 \%$. Tax avoidance in this study is measured using the cash effective tax rate (CETR). In 2018, tax revenues from the property, real estate and building construction sector amounted to IDR 83.51 trillion or $6.62 \%$ (Online-Pajak.com), lower than 2017 which amounted to $7.61 \%$ (katadata.co. id).

The following is an average graph that contains information about the CETR value, Company Size, Sales Growth and DAR (Leverage) of property and real estate sub-sector companies listed on the IDX for the period 2012-2018.

\footnotetext{
Agung Fajar IImiyono and Rima Auliyamartha Agustina. Company size, sales growth and leverage against tax avoidance in property and real estate companies on the Indonesian Stock Exchange for the period of 2012-2018
} 


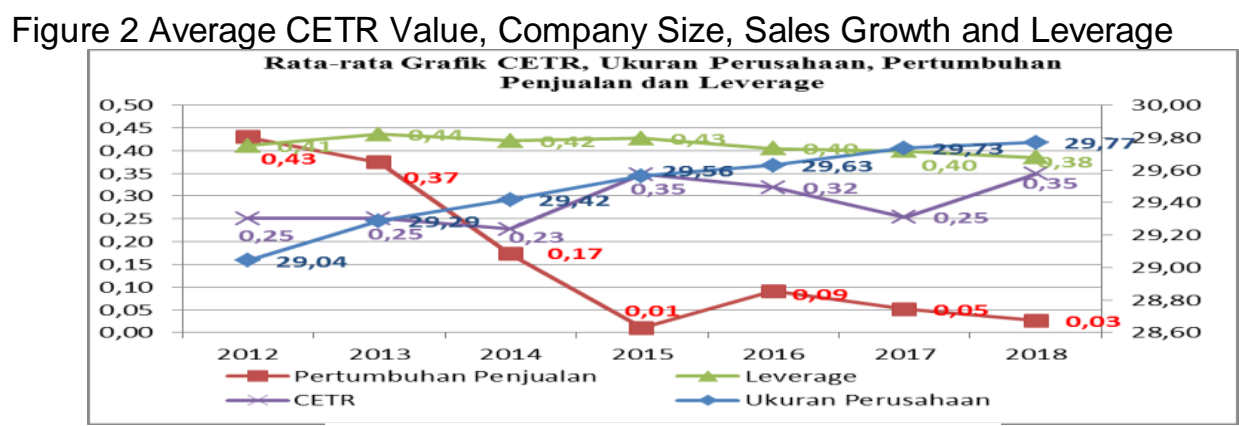

(Source: idx.co.id, data processed by the author, 2019)

The chart above shows that the property and real estate sub-sector companies avoided taxes in 2014 because they had a CETR value below 0.25 , while the size value has increased every year. This illustrates that company size has no effect on tax avoidance. This shows the incompatibility of the theory that has been put forward and is different from the results of researchers by Lestari et. Al., (2018), that the larger the size of the company, the greater the tax avoidance actions taken by the company.

The value of sales growth on the chart has decreased from 2012 to 2015, but continued to practice tax avoidance in 2014. Then in 2016 when the value of sales growth increased but did not do tax avoidance practices. This shows that there is a discrepancy with the theory put forward by Rahedi (2019) which states that sales growth has an effect on tax avoidance. This shows that the greater the sales growth rate of a company, the higher the level of tax avoidance practices of a company.

The leverage value of the chart above experiences a fluctuating state. In 2014 the leverage value decreased but the CETR value decreased, then in 2013 and 2015 when the leverage value increased but the CETR value increased or there was no tax avoidance practice. This shows that the incompatibility with the theory put forward by Wijayanti and Merkusiwati (2017) that leverage has an effect on tax avoidance, namely the greater leverage in the company can significantly affect the increase in tax avoidance practices that can occur.

The objectives of this research are the influence of company size, sales growth and leverage on tax avoidance in property and real estate sub-sector companies listed on IDX in the period 2012-2018.Previous research, Putri and Suryarini (2017) proved that the size of the company affects tax avoidance, Nafis, et al (2017) proves that the results of theirresearch on sales growth and leverage also affect tax avoidance. In Cahyana (2019) the results showed that sales growth and leverage had no effect on tax avoidance.

\section{Problem Formulation}

Based on the background of the problem that the author described, then the author can formulate the problem as follows:

1. Does the size of the company affect tax avoidance on property and real estate subsectors listed on the Indonesia Stock Exchange for the period 2012-2018?

2. Does sales growth affect tax avoidance in property and real estate subsectors listed on the Indonesia Stock Exchange for the period 2012-2018?

3. Does leverage affect tax avoidance on property and real estate subsectors listed on the Indonesia Stock Exchange for the period 2012-2018?

4. Does the size of the company, sales growth and leverage have a common influence on tax avoidance on property and real estate subsectors listed on the Indonesia Stock Exchange for the period 2012-2018?

Agung Fajar IImiyono and Rima Auliyamartha Agustina. Company size, sales growth and leverage against tax avoidance in property and real estate companies on the Indonesian Stock Exchange for the period of 2012-2018 


\section{LITERATURE REVIEW}

\section{Library Review and Hypothetical Development}

\section{Agency Theory}

According to Hendriksen and Breda (1992) in Kurniasih and Sari (2013) the Agency Theory states the contractual relationship between the agent (management of a business) and the principal (business owner). The agent performs certain duties for the principal, and the principal has an obligation to reward the agent, where the principal submits management authority to the management of the company. Meanwhile, the management of the company as a party authorized to manage the company has an obligation to provide and submit financial statements as a form of accountability to the principal. The agency's theory relates to the size of the company, sales growth and leverage in tax avoidance practices, where the management of the company if managing the size of the company, sales growth and leverage can well utilize it in conducting tax avoidance practices aimed at maximizing the profit earned by the company.

\section{Company Size}

According to Agustina and Aris (2016) in Primasari (2019) the size of the company is a scale that can classify the company into companies large and small by comparing the company's total assets, stock market value, average sales rate, and number of sales. According to Rego (2003) in Marfu'ah (2015) stated the larger the size of the company, the more complex the transaction will be. So it allows companies to exploit existing loopholes to take tax avoidance measures out of every transaction.

\section{Sales Growth}

According to Dewinta and Setiawan (2016) Sales growth is a calculation of increase or decrease in sales from year to year. With this sales growth ratio, companies can see how their business is growing year after year. The higher this ratio the better the company in running its business and the more likely it is to get the most profit. The higher the sales growth ratio then the resulting profit will increase. So the higher the level of sales then the company is likely to make a big profit.

\section{Leverage}

According to Darmawan and Sukartha (2014) Leverage is a ratio that indicates the amount of debt held by the company to finance its operations. The increase in the amount of debt will result in the appearance of interest expense to be paid by the company. The interest expense component will reduce the company's pre-taxable profit, so the tax burden that the company must pay will be reduced (Surbakti, 2012).

\section{Tax Avoidance}

Tax avoidance is an avoidance effort carried out by taxpayers legally that does not violate tax law by exploiting weaknesses in tax law with the aim of reducing the amount of tax owed. In another sense, companies deliberately commit tax evasion to reduce the payment of taxes that must be paid to the state, with the conduct of tax avoidance.

\section{Hypothetical Development}

The larger the size of the company the more complex the transaction will be. Thus, companies can exploit loopholes to conduct tax avoidance of every transaction that the company makes. Large and stable profits will tend to encourage companies to practice tax avoidance because large profits will cause a huge tax burden as well. Research conducted by Selviani,et al (2019), Fadhillah (2017), Putri and Suryarini (2017), Lestari,et al (2018), Susanti (2018), Dewi and Noviari (2017), Turyatini (2017), Dharma and Ardiana (2016) and Musyarofah (2016), showed the influence of the company's size on tax avoidance. Thus the hypothetical conclusions in this study are as follows:

Agung Fajar IImiyono and Rima Auliyamartha Agustina. Company size, sales growth and leverage against tax avoidance in property and real estate companies on the Indonesian Stock Exchange for the period of 2012-2018 


\section{$H_{1}$ : The Size of the Company affects}

Tax avoidance in the property and real estate sub-sectors listed on the Indonesia Stock Exchange in the period 2012 - 2018.

The larger the sales volume of a company indicates that the company's sales growth is increasing.If sales growth increases, the company's profit is assumed to increase.Rising corporate profits mean the tax paid by companies will get bigger so companies will be more likely to take tax avoidance measures. Research conducted by Rahedi (2019), Susanti (2018), Rahmawati, (2017), Fatimah (2018), Lestari,et al 2018), Nafis, et al (2017) and Purwanti and Sugiyarti (2017) showed sales growth affecting tax avoidance. Thus the hypothetical conclusions in this study are as follows:

\section{$\mathrm{H}_{2}$ : Sales Growth affects}

tax avoidance on property and real estate sub-sector companies listed on the Indonesia Stock Exchange in the period 2012 - 2018.

The higher the amount of funding from third-party debt used by the company and the higher the interest costs arising from the debt. Higher interest costs will have the effect of reducing the corporate tax burden. The higher the value of the company's debt, the lower the value of the company's CETR. Research conducted by Wijayanti and Merkusiwati (2017), Rachmithasari (2015), Dewi and Noviari (2017), Nafis, et al (2017), Dharma and Ardiana (2016), Musyarofah (2016), and Marfu'ah (2015) shows that leverage affects tax avoidance. Thus the hypothetical conclusions in this study are as follows:

\section{$\mathrm{H}_{3}$ : Leverage affects on}

tax avoidance on property and real estate sub-sector companies listed on the Indonesia Stock Exchange in the period of 2012 - 2018.

The effect of the size of the company, sales growth and leverage on tax avoidance is that the larger the size of the company, the higher the sales growth and the higher the leverage, the lower the value of CETR that it can expect tax avoidance measures. Researchers conducted by Nafis, et al (2017) showed the influence of the size of the company, sales growth and leverage on tax avoidance. Thus the hypothetical conclusions in this study are as follows:

\section{$\mathrm{H}_{4}$ : Company Size, Sales Growth and Leverage}

are jointly affect tax avoidance on property and real estate sub-sector companies listed on the Indonesia Stock Exchange in the period 2012 - 2018.

\section{RESEARCH METHODOLOGY}

The sample selected using purposive sampling method is the sample selected using certain considerations tailored to the purpose of the research or research issues developed. The sample used in this study was a Property and Real Estate company listed on the Indonesia Stock Exchange, published a complete annual report on both annual report and financial report for 2011-2018, using rupiah and never experiencing losses during the research period of 2012- 2018.

The data used is secondary data which is the data of financial statements, which is sampled available on the website of the Indonesia Stock Exchange (www.idx.co.id), IDN Financials and the website of each company

.In this study, the independent variables namely the size of the company, sales growth and leverage while being dependent variables are tax avoidance Operationalization variables in this study are as follows:

Agung Fajar IImiyono and Rima Auliyamartha Agustina. Company size, sales growth and leverage against tax avoidance in property and real estate companies on the Indonesian Stock Exchange for the period of 2012-2018 
The Accounting Journal of BINANIAGA Vol. 05, No. 02, December 2020

p-ISSN: 2527-4309, e-ISSN: 2580-1481

$5^{\text {th }}$ Accreditation Rating: January 14, 2019 - January 13, 2024

Table 1 Operational Variables

\begin{tabular}{|c|c|c|c|}
\hline Variable & Indicator & Measure & Scale \\
\hline Company Size $(\mathrm{X} 1)$ & $\begin{array}{l}\text { Natural Logarithm } \\
\text { (Total Assets) }\end{array}$ & Company Size = Ln Total Asset & Ratio \\
\hline Sales Growth (X2) & Sales Growth & $\frac{\text { Sales Year Now - Previous Year Sales }}{\text { Previous Year Sales }}$ & Ratio \\
\hline Leverage (X3) & $\begin{array}{l}\text { Debt to Asset Ratio } \\
\text { (DAR) }\end{array}$ & $D A R=\frac{\text { Total Debt }}{\text { Total Asset }}$ & Ratio \\
\hline Tax Avoidance (Y) & $\begin{array}{l}\text { Cast Effective Tax } \\
\text { Rate (CETR) }\end{array}$ & CETR $=\frac{\text { Amount of Cash paid for Tax }}{\text { Profit before Tax }}$ & Ratio \\
\hline
\end{tabular}

\section{RESULT AND DESCRIPTION}

\section{RESULTS}

\section{Classical Assumption Test}

Table 2 Normality Test Results

One-Sample Kolmogorov-Smirnov Test

Unstandardized

Residual

\begin{tabular}{llr}
\hline \multirow{2}{*}{$\mathrm{N}$} & & 103 \\
Normal Parameters ${ }^{\mathrm{a}, \mathrm{b}}$ & Mean & .0000000 \\
\cline { 2 - 3 } & Std. Deviation & .22775285 \\
\hline Most Extreme Differences & Absolute & .067 \\
\cline { 2 - 3 } & Positive & .067 \\
\cline { 2 - 3 } & Negative & \\
\hline Test Statistic & & .060 \\
\hline Asymp. Sig. (2-tailed) & .067 \\
\hline
\end{tabular}

a. Test distribution is Normal.

b. Calculated from data.

c. Lilliefors Significance Correction.

d. This is a lower bound of the true significance.

Source: Data Processing Results, 2019

Asymp signification value, Sig. (2-tailed) obtained is 0.200 . Because the resulting signification value is above 0.05 then the residual value is normal. So this research model is stated to have fulfilled the assumption of normality.

\footnotetext{
Agung Fajar IImiyono and Rima Auliyamartha Agustina. Company size, sales growth and leverage against tax avoidance in property and real estate companies on the Indonesian Stock Exchange for the period of 2012-2018
} 
The Accounting Journal of BINANIAGA Vol. 05, No. 02, December 2020

\section{MulticolinearityTest}

Table 3 Multicolinearity Test Results

\begin{tabular}{|c|c|c|c|c|c|c|c|}
\hline \multirow[b]{3}{*}{ Model } & \multicolumn{7}{|c|}{ Coefficients a } \\
\hline & $\begin{array}{l}\text { Unstandardize } \\
\text { Coefficients }\end{array}$ & & $\begin{array}{l}\text { Standardized } \\
\text { Coefficients }\end{array}$ & & & Collineari & stics \\
\hline & B & Error & Beta & $\mathrm{t}$ & sig. & Tolerance & IVIF \\
\hline (Constant) & 1.552 & 748 & & 2.076 & .040 & & \\
\hline$\left(\mathrm{X}_{1}\right)$ & -.066 & 024 & -.256 & -2.737 & .007 & .868 & 1.152 \\
\hline$\left(\mathrm{X}_{2}\right)$ & -.059 & 048 & -.108 & -1.231 & .221 & .994 & 1.006 \\
\hline$\left(\mathrm{X}_{3}\right)$ & .897 & 166 & .506 & 5.394 & .000 & .863 & 1.158 \\
\hline
\end{tabular}

Source: Data Processing Results, 2019

Based on the table above shows all variable values $X$ above tolerance value 0.10 among others namely the company size value $(X 1)$ of 0.868 , the value of sales growth (X2) of 0.994 and the leverage value (X3) of 0.863 .In addition, the value of VIF is smaller than 10.00 , namely the size of the company $(X 1)$ of 1,152 , the value of sales growth $(X 2)$ of 1,006 and the leverage value $(X 3)$ of 1,158 . Then it can be concluded that in the regression model there is no problem of multicollinearity.

\section{Heteroskedastisity Test}

Figure 4 Heteroskedastisity Test Results

Scatterplot

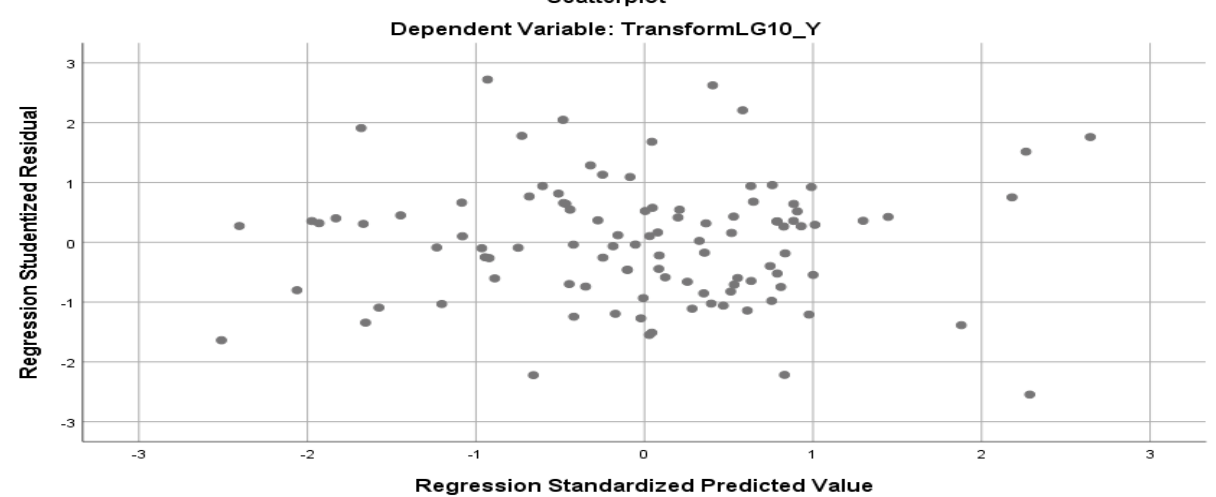

Source: Data Processing Results, 2019

Based on the Scatter Plot chart above, it can be concluded that there is no heteroskedastisity in the regression model because the Scatter Plot chart shows an obscure pattern, as well as the dots above and below the number 0 on the $\mathrm{Y}$ axis.

Agung Fajar IImiyono and Rima Auliyamartha Agustina. Company size, sales growth and leverage against tax avoidance in property and real estate companies on the Indonesian Stock Exchange for the period of 2012-2018 
The Accounting Journal of BINANIAGA Vol. 05, No. 02, December 2020 p-ISSN: 2527-4309, e-ISSN: 2580-1481

$5^{\text {th }}$ Accreditation Rating: January 14, 2019 - January 13, 2024

\section{Autocorrelation Test}

Table 4 Autocorrelation Test Results

\section{Runs Test}

\begin{tabular}{cr} 
& \multicolumn{1}{c}{$\begin{array}{c}\text { Unstandardized } \\
\text { Residual }\end{array}$} \\
\hline Test Value $^{\text {a }}$ & .02260 \\
\hline Cases $<$ Test Value & 51 \\
\hline Cases $>=$ Test & 52 \\
Value & 103 \\
\hline Total Cases & 43 \\
\hline Number of Runs & -1.881 \\
\hline Z & .060 \\
\hline Asymp. Sig. (2- & \\
\hline tailed)
\end{tabular}

a. Median

Source: Data Processing Results, 2019

Based on the table above asymp.sig (2-tailed) results of 0.06 greater than 0.05 , it can be concluded that there are no symptoms of auto correlation. So the regression model can be said to be good.

\section{Multiple Linear Regression Analysis Test}

Table 5 Multiple Linear Regression Analysis Test Results

\begin{tabular}{|c|c|c|c|c|c|}
\hline \multicolumn{6}{|c|}{ Coefficients ${ }^{a}$} \\
\hline \multirow{2}{*}{ Model } & \multicolumn{2}{|c|}{ Unstandardized Coefficients } & \multirow{2}{*}{$\begin{array}{r}\text { Standardized } \\
\text { Coefficients } \\
\text { Beta }\end{array}$} & \multirow[b]{2}{*}{$\mathrm{T}$} & \multirow[b]{2}{*}{ Sig. } \\
\hline & B & Std. Error & & & \\
\hline (Constant) & 1.552 & .748 & & 2.076 & .040 \\
\hline $\mathrm{x} 1$ & -.066 & .024 & -.256 & -2.737 & .007 \\
\hline$x 2$ & -.059 & .048 & -.108 & -1.231 & .221 \\
\hline $\mathrm{x} 3$ & .897 & 166 & .506 & 5.394 & .000 \\
\hline
\end{tabular}

a. Dependent Variable: CETR

Source: Data Processing Results, 2019

The results in the table 5 can be modeled linear regression equations as follows:

$Y=\alpha+\beta 1 X 1+\beta 2 X 2+\beta 3 X 3+e$

$Y=1,552-(0.066)$ Company Size $-(0.059)$ Sales Growth $+(0.897)$ Leverage $+e$

Caption:

$\mathrm{Y} \quad=$ Tax avoidance

Agung Fajar IImiyono and Rima Auliyamartha Agustina. Company size, sales growth and leverage against tax avoidance in property and real estate companies on the Indonesian Stock Exchange for the period of 2012-2018 


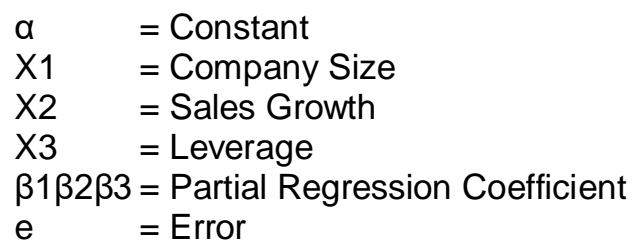

The equation above explains that:

1. Constant

The constant value of 1.552 shows that if an independent variable (company size, sales growth and leverage) is assumed to be equal to zero, then CETR will increase by 1.552

2. Company Size Variable Regression Coefficient

The company size coefficient value of -0.066 means that if the Variable Size of the Company increases by 1 time then CETR will decrease by -0.066 .

3. Sales Growth Variable Regression Coefficient

The coefficient value of Sales Growth of -0.059 means that if the variable Sales Growth increases by 1 time then CETR will decrease by -0.059 .

4. Leverage Variable Regression Coefficient Leverage coefficient value of 0.897 means that if leverage variables increase by 1 time then CETR will increase by 0.897 .

\section{Hypothesis Test}

\section{Partial Regression Coefficient Test (t Test)}

\begin{tabular}{l|l|l|l|l}
\multicolumn{7}{c}{ Table 6. $\mathrm{t}$ Test Results } \\
Coefficients
\end{tabular}

Source: Data Processing Results, 2019

Hypothesis Testing $\left(\mathrm{H}_{1}\right)$

Known sig. value for enterprise size influence $\left(\mathrm{X}_{1}\right)$ against CETR $(\mathrm{Y})$ is $0.007<0.05$ and $t$ value count $-2.737>\mathrm{t}$ table -1.97669 , so it can be concluded that $\mathrm{H} 1$ accepted there is an $\mathrm{X}_{1}$ effect on $\mathrm{Y}$.

Hypothesis Testing $\left(\mathrm{H}_{2}\right)$

Known sig. value for the effect of sales growth $\left(\mathrm{X}_{2}\right)$ on CETR $(\mathrm{Y})$ is $0.221>0.05$ and $t$ value count $-1.231<\mathrm{t}$ table -1.97669 , so it can be concluded that $\mathrm{H} 2$ in reject has no $\mathrm{X} 2$ effect on $\mathrm{Y}$.

Agung Fajar IImiyono and Rima Auliyamartha Agustina. Company size, sales growth and leverage against tax avoidance in property and real estate companies on the Indonesian Stock Exchange for the period of 2012-2018 
The Accounting Journal of BINANIAGA Vol. 05, No. 02, December 2020

p-ISSN: 2527-4309, e-ISSN: 2580-1481

$5^{\text {th }}$ Accreditation Rating: January 14, 2019 - January 13, 2024

Hypothesis Testing $\left(\mathrm{H}_{3}\right)$

Known sig. value for DAR influence (X3) on CETR $(Y)$ is $0.000<0.05$, and t value count $5,394>t$ table 1.97669 , so it can be concluded that $\mathrm{H} 3$ is accepted there is an $\mathrm{X} 3$ effect on $\mathrm{Y}$.

\section{Simultaneously Regression Coefficient Testing (F Test)}

Table 7 F Test Results

\begin{tabular}{|c|c|c|c|c|c|}
\hline \multicolumn{6}{|c|}{ ANOVA $^{a}$} \\
\hline Model & $\begin{array}{l}\text { Sum of } \\
\text { Squares }\end{array}$ & $d f$ & $\begin{array}{l}\text { Mean } \\
\text { Square }\end{array}$ & $\mathrm{F}$ & Sig. \\
\hline $\begin{array}{l}\text { Regressi } \\
\text { on }\end{array}$ & 1.741 & 3 & .580 & 10.858 & $.000^{\mathrm{b}}$ \\
\hline Residual & 5.291 & 99 & .053 & & \\
\hline Total & 7.032 & 102 & & & \\
\hline $\begin{array}{l}\text { a. Depe } \\
\text { b. Predic } \\
\left(X_{2}\right), \text { Com }\end{array}$ & $\begin{array}{l}\text { dent Variab } \\
\text { ors: (Consta } \\
\text { any Size ( } X_{1}\end{array}$ & $\begin{array}{l}\text { e: CET } \\
\text { t), DA }\end{array}$ & $\begin{array}{l}(Y) \\
\left(X_{3}\right), \text { Sale }\end{array}$ & s Growt & \\
\hline
\end{tabular}

Source: Data Processing Results, 2019

Based on the table above known the signification value for the influence of the company size (X1), sales growth (X2) and leverage (X3) simultaneously against tax CETR $(Y)$ is $0.000<0.05$ and the value of $F$ calculates $10,858>F$ table 2.67 , so it can be concluded that $\mathrm{H} 3$ is accepted which means there is an influence of $\mathrm{X} 1, \mathrm{X} 2$ and $\mathrm{X} 3$ simultaneously on $\mathrm{Y}$.

\section{Determination Coefficient Testing $\left(\mathbf{R}^{2}\right)$}

\section{Table 8 Determination Coefficient Test Results}

\begin{tabular}{rl|r|r|r|r}
\multicolumn{70}{c}{ Model Summary } \\
Model & $\mathrm{R}$ & $\begin{array}{c}\text { b } \\
\text { Square }\end{array}$ & $\begin{array}{l}\text { Adjusted } \\
\text { R Square }\end{array}$ & $\begin{array}{l}\text { Std. Error } \\
\text { of the } \\
\text { Estimate }\end{array}$ & $\begin{array}{l}\text { Durbin- } \\
\text { Watson }\end{array}$ \\
\hline 1 & $.498^{\mathrm{a}}$ & .248 & .225 & .23118 & 1.380 \\
\hline
\end{tabular}

a. Predictors: (Constant), Leverage $\mathrm{X}_{3}$, Sales Growth $\mathrm{X}_{2}$, Company SizeX 1

b. Dependent Variable: CETR

Source: Data Processing Results, 2019

Based on the test results of the above determination coefficient, the value of Adjusted $\mathrm{R}$ square is 0.225 or $22.5 \%$. This means an independent variable influence contribution to dependent variables of $22.5 \%$ while $77.5 \%$ is explained by other variables not contained in this study.

\footnotetext{
Agung Fajar IImiyono and Rima Auliyamartha Agustina. Company size, sales growth and leverage against tax avoidance in property and real estate companies on the Indonesian Stock Exchange for the period of 2012-2018
} 


\section{DESCRIPTION}

\section{The Effect of The Company's Size on Tax Avoidance on Property sub-sectors and real estate companies registered in IDX for the period 2012-2018}

Based on the test results conducted by researchers, the size of the company with the natural logarithm proxies of total assets affects tax avoidance with CETR proxies. This is evidenced by the larger the size of the company then the value of CETR will decrease this means the higher the tax avoidance practice. This indicates that the size of the company affects CETR.

Large-scale companies have large assets as well, making them more capable and more stable to make a profit when compared to companies with small total assets. Large and stable profits will likely encourage companies to practice tax avoidance. This condition leads to an increase in the amount of tax burden that encourages companies to commit tax avoidance. Large companies have superior resource quality compared to small companies. Expert resources in taxation are used by corporate management in doing the best possible tax planning to minimize the corporate tax burden. Small-scale companies cannot manage their tax burden optimally because of experts in the field of minimal taxation.

The results of this research are in line with tLestari,et al (2018), Dewi and Noviari (2017), Musyarofah (2016) and Fadhillah (2017) which found that the Size of the Company affects CETR.

\section{Effect of Sales Growth on Tax Avoidance on Property sub-sector and real estate companies registered in IDX period 2012-2018}

Based on the test results conducted by researchers, sales growth has no effect on tax avoidance with CETR proxies. This is evidenced by the value of sig. for the effect of sales growth (X2) on CETR $(Y)$ is $0.221>0.05$ and the t-count value is $-1,231<t$ table 1.97669.This indicates that sales growth has no effect on CETR.

The company's sales growth does not affect the company's decision to conduct tax avoidance because companies with increased or declining sales growth have the same obligation to pay taxes.In addition, the Company will continue to avoid tax despite low sales growth. This is because the company wants to minimize the tax burden to earn a bigger profit.

The results of this research are in line with Cahyana (2019) and Turyatini (2017) which found that sales growth had no effect on CETR.

\section{Effect of the Leverage on Tax Avoidance on Property Sub-Sector companies and Real Estate Registered in IDX period 2012 -2018}

Based on the test results conducted by researchers, leverage with debt to asset ratio (DAR) proxy affects tax avoidance with CETR proxy. This is evidenced by the value of sig. for leverage influence (X3) against CETR (Y) is $0.000<0.05$ and the calculated $t$ value is $5,394>t$ table 1,996. This indicates that the greater the value of the company's DAR then the higher the value of CETR, this means the lower the level of tax avoidance practices. This indicates that leverage affects CETR.

The company with a high DAR value describes that the company uses its debt to finance its operational activities that will bring about the interest expense as a result the profit earned by the company will be reduced so that the tax to be paid by the company will be reduced as well or will be lower so that it does not intentionally conduct tax avoidance practices. The low tax burden will have an impact on the decline in tax avoidance efforts. According to Noor (2010) in Dewinta and Setiawan (2016) which

Agung Fajar IImiyono and Rima Auliyamartha Agustina. Company size, sales growth and leverage against tax avoidance in property and real estate companies on the Indonesian Stock Exchange for the period of 2012-2018 
explains that companies with more debt have a good effective tax rate, this means that with a large amount of debt, companies to do tax avoidance will tend to be lower.

The results of this research are in line with Nafis, et al (2017), Wijayanti and Merkusiwati (2017) which found that Leverage affects CETR.

\section{Effect of Company Size, Sales Growth and Leverage on Tax Avoidance in Property and Real Estate Sub-Sector Companies Registered in IDX period 2012-2018}

Based on the results of tests conducted by researchers found that, the Size of the Company, Sales Growth and Leverage have a simultaneous effect on CETR. This is evidenced by the signification value for the influence of the company size $(X 1)$, sales growth (X2) and leverage (X3) simultaneously against CETR (Y) is $0.000<0.05$ and the value of $F$ calculates $10,858>F$ table 2.67 .

Large companies' size with high sales growth rates will be bolder to make loans to third parties, because these companies feel able to repay loans and also third parties believe if lending to companies grouped by large companies is certainly more able in generating profit, because it sees good company performance. If the company owes more, it will incur the interest expense paid by the company. Where interest expense can be used as a deduction of taxable profit stipulated in Law No. 36 of 2008 article 6, paragraph 1 thereby reducing the payment of tax expense.

Hasil penelitian ini sejalan dengan penelitian Nafis, dkk (2017) menemukan Ukuran Perusahaan, Pertumbuhan Penjualan dan Leverage berpengaruh secara bersama-sama terhadap Tax Avoidance.

The results of this research are in line with Nafis, et al (2017) found the Size of the Company, Sales Growth and Leverage have a joint effect on Tax Avoidance.

\section{CONCLUSIONS AND SUGGESTIONS}

\section{CONCLUSIONS}

Based on data analysis and the discussion that has been done regarding the influence of company size, sales growth and leverage on tax avoidance in property and real estate companies listed on the IDX in 2012-2018, here are some conclusions that the authors can draw from the results of this study:

1. The Size of the Company affects CETR. This indicates the size of the company can be an indicator in doing tax avoidance. Property and real estate companies use assets for operational activities to increase the company's profits in order to become a grouped company into a large company. So it has the quality of expert resources in taxation used by the management of companies to conduct tax avoidance.

2. Sales growth has no effect on CETR. This indicates sales growth cannot be an indicator in tax avoidance. Companies with increased and declining sales growth will continue to do tax avoidance. This is because the company wants to minimize the tax burden to earn a bigger profit.

3. Leverage affects CETR. This indicates leverage can be an indicator in tax avoidance. The average leverage on property and real estate companies uses debt for operational activities to increase the company's profits, which will incur an interest expense to be paid. So as to reduce the corporate tax burden then inadvertently conduct tax avoidance practices.

4. Company size, sales growth and leverage affect CETR. With these results, property and real estate companies take advantage of tax avoidance techniques to reduce the tax burden that companies have to pay, with several factors affecting total assets, sales growth and debt.

\footnotetext{
Agung Fajar IImiyono and Rima Auliyamartha Agustina. Company size, sales growth and leverage against tax avoidance in property and real estate companies on the Indonesian Stock Exchange for the period of 2012-2018
} 


\section{SUGGESTIONS} follows:

The suggestion that can be conveyed regarding or related to this research is as

1. For practitioners it is expected that the results of this study can be developed to solve problems related to tax avoidance in the company. And it is hoped that companies grouped into large corporations can do better tax planning.

2. For academics are expected to further research into other issues, that could affect tax avoidance. It is also expected to add other variables that could affect tax avoidance such as independent commissioners, DER, audit committees and transfer pricing.

\section{REFERENCES}

Cahyana, V. (2019). Pengaruh Komite Audit, Ukuran Perusahaan, Profitabilitas, Leverage, Dan Pertumbuhan Penjualan Terhadap Tax Avoidance Pada Perusahaan Manufaktur. [online]. Sekolah Tinggi Ilmu Ekonomi Perbanas Surabaya. url: http://eprints.perbanas.ac.id/4420/1/ARTIKEL ILMIAH.pdf.

Darmawan, I., dan Sukartha, I. (2014) 'Pengaruh Penerapan Corporate Governance, Leverage, Roa, Dan Ukuran Perusahaan Pada Penghindaran Pajak'. E-Jurnal Akuntansi.[online], 9(1),143-161.url: https://ojs.unud.ac.id/index.php/Akuntansi/article/download/8635/7643.

Dewi, N., dan Noviari, N. (2017). Pengaruh Ukuran Perusahaan, Leverage, Profitabilitas Dan Corporate Social Responsibility Terhadap Penghindaran Pajak (Tax Avoidance).E-Jurnal Akuntansi Universitas Udayana.[online], 21, 830-859. url: https://ojs.unud.ac.id/index.php/Akuntansi/article/view/34029.

Dewinta, I., dan Setiawan, P. (2016). Pengaruh ukuran perusahaan, umur perusahaan, profitabilitas, leverage, dan pertumbuhan penjualan terhadap tax avoidance. E$\begin{array}{lrr}\text { Jurnal Akuntansi. } & \text { [online], 14, } & \text { 1584-1615 } \\ \text { https://ojs.unud.ac.id/index.php/Akuntansi/article/view/16009. }\end{array}$

Dharma, I., dan Ardiana, P. (2016). Pengaruh Leverage, Intensitas Aset Tetap, Ukuran Perusahaan, Dan Koneksi Politik Terhadap Tax Avoidance. E-Jurnal Akuntansi. [online], 15(1), 584-613.

url: https://ojs.unud.ac.id/index.php/Akuntansi/article/view/17463/13432.

Direktorat Jenderal Pajak. (2018).Rasio Pajak (Tax Ratio) dari Masa ke Masa.

Pajak.go.id. url : https://www.pajak.go.id/id/86-rasio-pajak-tax-ratio-dari-masa-ke-masa/.

Fadhillah, P. (2017). The Influence Of Leverage And Firm Size To Tax Avoidance (Case Study on Sub Sector Coal Company Listed in Indonesia Stock Exchange Period 2012-2016). [online]. Faculty Of Economics And Business Indonesia Computer University. url: https://elib.unikom.ac.id/files/disk1/751/jbptunikompp-gdlputrirahay-37546-1-unikom_p-e.pdf.

Fatimah, N. (2018). Pengaruh Kepemilikan Institusional, Komite Audit, Ukuran Perusahaan, Profitabilitas, Leverage, dan Pertumbuhan Penjualan terhadap Tax Avoidance. [online]. Skripsi. Universitas Islam Indonesia Yogyakarta. url: https://dspace.uii.ac.id/bitstream/handle/123456789/7648/

Agung Fajar IImiyono and Rima Auliyamartha Agustina. Company size, sales growth and leverage against tax avoidance in property and real estate companies on the Indonesian Stock Exchange for the period of 2012-2018 
The Accounting Journal of BINANIAGA Vol. 05, No. 02, December 2020

p-ISSN: 2527-4309, e-ISSN: 2580-1481

$5^{\text {th }}$ Accreditation Rating: January 14, 2019 - January 13, 2024

Friana,H.(2019). DJP Dalami Dugaan Penghindaran Pajak PT Adaro Energy.tirto.id. url : https://tirto.id/djp-dalami-dugaan-penghindaran-pajak-pt-adaro-energy-edKk.

Kementrian Keuangan Republik Indonesia. (2018). APBN 2018. Kemenkeu.go.id. url : https://www.kemenkeu.go.id/apbn2018.

Kementrian Keuangan Republik Indonesia. (2017). Pertumbuhan Ekonomi Indonesia Tahun 2018 Lebih Tinggi Dari Tahun 2017. Kemenkeu.go.id. url : https://www.kemenkeu.go.id/publikasi/berita/pertumbuhan-ekonomi-indonesiatahun-2018-lebih-tinggi-dari-tahun-2017/.

Kurniasih, T., \& Sari, M. (2013). Pengaruh Return on Assets, Leverage, Corporate Governance, Ukuran Perusahaan Dan Kompensasi Rugi Fiskal Pada Tax Avoidance. Buletin Studi Ekonomi. [online], 18(1), 58-66. url: https://ojs.unud.ac.id/index.php/bse/article/download/6160/4647.

Lestari, P., Harimurti, F.\& Suharno. (2018).Pengaruh Karakteristik Perusahaan Dan Sales Growth Terhadap Tax Avoidance (Studi Kasus pada Perusahaan Manufaktur Sektor Makanan dan Minuman yang Terdaftar di BEI tahun 2013 - 2016). Jurnal Akuntansi dan Sistem Teknologi Informasi.,14(2), 551-559. url: https://ejurnal.unisri.ac.id/index.php/Akuntansi/article/view/2971/2554.

Marfu'ah, L. (2015) 'Pengaruh Return on Asset, Leverage , Ukuran Perusahaan , Kompensasi Rugi Fiskal dan Kepemilikan Institusi Terhadap Penghindaran Pajak.[Online]. pp. 1-25. Universitas Muhammadiyah Surakarta. url: http://eprints.ums.ac.id/37022/1/NASKAH PUBLIKASI.pdf.

Musyarofah, E.(2016). Pengaruh Derivatif Keuangan, Leverage Dan Ukuran Perusahaan Terhadap Penghidaran Pajak (Tax Avoidance). [online]. Skripsi. Universitas Islam Negeri Syarif Hidayatullah. url; http://repository.uinjkt.ac.id/dspace/bitstream/123456789/35655/1/EVA MUSYAROFAH-FEB.pdf.

Nafis, M., dan Fatahurrazak (2017). Pengaruh Return On Asset (Roa), Capital Intensity, Sales Growth, Debt To Asset Ratio (Dar), Dan Firm Size Terhadap Penghindaran Pajak (Tax Avoidance) Pada Perusahaan Manufaktur Yang Terdaftar Di Bursa Efek Indonesia Periode 2012-2016. Jurnal Universitas Maritim Raja Ali Haj [online], 28(2), 250-250. url: http://repository.umrah.ac.id/1274/1/MUHAMMAD NAFIS-140462201067-FE-2018.pdf.

Online Pajak.(2019). Penerimaan Pajak Tumbuh Lebih Tinggi di 2018.Online-Pajak.com. url: https://www.online-pajak.com/penerimaan-pajak-tumbuh-lebih-tinggi-di-2018.

Primasari, N. (2019). Leverage, Ukuran Perusahaan, Profitabilitas, Pertumbuhan Penjualan, Proporsi Komisaris Independen Dan Kualitas Audit Terhadap Tax Avoidance (Studi Empiris pada Perusahaan Manufaktur yang terdaftar di Bursa Efek Indonesia Periode 2014-2016). Jurnal Akuntansi dan Keuangan, 23(3). url: https://journal.budiluhur.ac.id/index.php/akeu/article/viewFile/838/647

Purwanti, M., dan Sugiyarti, L. (2017). Pengaruh Intensitas Aset Tetap , Pertumbuhan Penjualan dan Koneksi. Jurnal Riset Akuntansi Dan Keuangan. [online], 5(3), 1625-1641. url: http://ejournal.upi.edu/index.php/JRAK/article/view/9225/5823.

\footnotetext{
Agung Fajar IImiyono and Rima Auliyamartha Agustina. Company size, sales growth and leverage against tax avoidance in property and real estate companies on the Indonesian Stock Exchange for the period of 2012-2018
} 
Putri, T., dan Suryarini,T.,.(2017).Factors Affecting Tax Avoidance on Manufacturing Companies Listed on IDX. [online], 6(3), 407-419. url: https://journal.unnes.ac.id/sju/index.php/aaj/article/view/18198.

Rachmithasari,A. (2015). Pengaruh Return On Assets, Leverage, Corporate Governance, Ukuran Perusahaan Dan Kompensasi Rugi Fiskal Pada Tax Avoidance. [online]. Universitas Muhammadiyah url http://eprints.ums.ac.id/36892/1/NASKAH\%20PUBLIKASI.pdf.

Rahedi, S. (2019) Pengaruh Intensitas Aset Tetap Dan Sales Growth Terhadap Tax Aoidance Dengan Dewan Komisaris Independen Sebagai Variabel Moderating (Studi Kasus Pada Perusahaan Manufaktur Yang Terdaftar Di Bei Periode 20152017). Journal of Chemical Information and Modeling. [online]. url: http://repositori.uin-

alauddin.ac.id/14007/1/PENGARUH\%20INTENSITAS\%20ASET\%20TETAP\%20 DAN\%20SALES\%20GROWTH.pdf.

Rahmawati, L. (2017). Pengaruh Intensitas Modal, Sales Growth, Dan Karakter Eksekutif Terhadap Tax Avoidance Dengan Leverage Sebagai Variabel Intervening. Iosr Journal of Economics and Finance.[online].3(1), pp. 1-217. url: http://repository.umy.ac.id/bitstream/handle/123456789/17163/Naskah Publikasi_Latif Rahmawati.pdf?sequence=12\&isAllowed=y.

Selviani,dkk. (2019). Pengaruh Ukuran Perusahaan dan Leverage terhadap Penghindaran Pajak Studi Kasus Empiris Pada Perusahaan Sub Sektor Kimia di Bursa Efek Indonesia Periode 2013 - 2017. [online]. 2(5), pp. 1-15. Universitas Pakuan. Url: https://jom.unpak.ac.id/index.php/akuntansi/article/viewFile/1072/829.

Surbakti, T. (2012). Pengaruh Karakteristik Perusahaan dan Reformasi Perpajakan Terhadap Penghindaran Pajak di Perusahaan Industri Manufaktur yang terdaftar di Bursa Efek Indonesia Tahun 2008-2010. Tesis, p. Universitas Indonesia.[online]. Url: http://lib.ui.ac.id/file?file=digital/20298969-S-Theresa Adelina Victoria Surbakti.pdf.

Susanti, E. (2018). Pengaruh Profitabilitas, Leverage, Sales Growth Dan Ukuran Perusahaan Terhadap Penghindaran Pajak (Studi Empiris pada Perusahaan Sektor Pertambangan dan Sektor Pertanian yang Listing di Bursa Efek Indonesia 2012-2017).[online]. Skripsi. Universitas Islam Indonesia Yogyakarta. url; https://dspace.uii.ac.id/bitstream/handle/123456789/11022/Pengaruh

Profitabilitas \%28ROA\%29\%2C Leverage\%2C Ukuran Perusahaan\%2C Dan Sales Growth Terhadap Penghindara.pdf?sequence=1\&isAllowed=y.

Thertina,M.(2019). Penerimaan Pajak dari Empat Sektor Industri Utama Tumbuh Melambat. Katadata.co.id. url:https://katadata.co.id/berita/2019/01/03/penerimaan-pajak-dari-empat-sektorindustri-utama-tumbuh-melambat..

Turyatini.(2017). The Analysis of Tax Avoidance Determinant on The Property and Real Estate Companies. Jurnal Dinamika Akuntansi. [online]. 9(2), 143-153. url: https://journal.unnes.ac.id/nju/index.php/jda/article/download/10385/7452.

Undang- Undang Republik Indoneisa Nomor 36 tahun 2008 tentang Pajak Penghasilan pada pasal 17

Agung Fajar IImiyono and Rima Auliyamartha Agustina. Company size, sales growth and leverage against tax avoidance in property and real estate companies on the Indonesian Stock Exchange for the period of 2012-2018 
The Accounting Journal of BINANIAGA Vol. 05, No. 02, December 2020

p-ISSN: 2527-4309, e-ISSN: 2580-1481

$5^{\text {th }}$ Accreditation Rating: January 14, 2019 - January 13, 2024

Undang- Undang Republik Indoneisa Nomor 36 tahun 2008 tentang Perubahan Keempat atas Undang- Undang Nomor 7 tahun 1983 tentang Pajak Penghasilan pada pasal 6 ayat 1

Wijayanti, Y., \& Merkusiwati, N. (2017). Pengaruh Proporsi Komisaris Independen, Kepemilikan Institusional, Leverage, Dan Ukuran Perusahaan Pada Penghindaran Pajak. E-Jurnal Akuntansi. [online], 20, 699-728. url: https://ojs.unud.ac.id/index.php/Akuntansi/article/download/29796/19370.

Agung Fajar IImiyono and Rima Auliyamartha Agustina. Company size, sales growth and leverage against tax avoidance in property and real estate companies on the Indonesian Stock Exchange for the period of 2012-2018

Page : 100 